\title{
Translational invasion ecology: bridging research and practice to address one of the greatest threats to biodiversity
}

\author{
Toni Lyn Morelli $\mathbb{D}$ - Carrie J. Brown-Lima · Jenica M. Allen · Evelyn M. Beaury • \\ Emily J. Fusco • Audrey Barker-Plotkin • Brittany B. Laginhas • \\ Brendan R. Quirion • Bridget Griffin - Blair McLaughlin • Lara Munro • \\ Nancy Olmstead $\cdot$ Julie Richburg $\cdot$ Bethany A. Bradley
}

Received: 16 June 2020/ Accepted: 14 June 2021 / Published online: 4 July 2021

(C) This is a U.S. government work and not under copyright protection in the U.S.; foreign copyright protection may apply 2021

\begin{abstract}
Effective natural resource management and policy is contingent on information generated by research. Conversely, the applicability of research depends on whether it is responsive to the needs and constraints of resource managers and policy makers. However, many scientific fields including invasion ecology suffer from a disconnect between research and practice. Despite strong socio-political imperatives, evidenced by extensive funding dedicated to addressing invasive species, the pairing of invasion ecology with stakeholder needs to support effective management and policy is lacking. As a potential solution, we propose translational invasion ecology (TIE). As an extension of translational ecology, as a framework to increase collaboration among scientists,
\end{abstract}

\section{T. L. Morelli $(\square)$}

Northeast Climate Adaptation Science Center, US

Geological Survey, Amherst, MA, USA

e-mail: tmorelli@usgs.gov

T. L. Morelli · E. J. Fusco - A. Barker-Plotkin .

B. Griffin · L. Munro · B. A. Bradley

Department of Environmental Conservation, University of Massachusetts, Amherst, MA, USA

T. L. Morelli · E. M. Beaury · B. B. Laginhas ·

B. A. Bradley

Organismic and Evolutionary Biology, University of

Massachusetts, Amherst, MA, USA

C. J. Brown-Lima

New York Invasive Species Research Institute, Cornell

University, Ithaca, NY, USA practitioners, and policy makers to reduce negative impacts of invasive species. As an extension of translational ecology, TIE is an approach that embodies an intentional and inclusive process in which researchers, stakeholders, and decision makers collaborate to develop and implement ecological research via joint consideration of the ecological, sociological, economic, and/or political contexts in order to improve invasive species management. TIE ideally results in improved outcomes as well as shared benefits between researchers and managers. We delineate the steps of our proposed TIE approach and describe successful examples of ongoing TIE projects from the US and internationally. We suggest practical ways to begin incorporating TIE into

J. M. Allen

Miller Worley Center for the Environment, Mount

Holyoke College, South Hadley, MA, USA

\section{B. R. Quirion}

Department of Natural Resources and the Environment,

Cornell University, Ithaca, NY, USA

B. McLaughlin

Hampshire College, Amherst, MA, USA

N. Olmstead

Department of Agriculture, Conservation and Forestry,

Maine Natural Areas Program, Augusta,

ME, USA

J. Richburg

The Trustees, Boston, MA, USA 
research and management practices, including supporting boundary-spanning organizations and activities, expanding networks, sharing translational experiences, and measuring outcomes. We find that there is a need for strengthened boundary spanning, as well as funding and recognition for advancing translational approaches. As climate change and globalization exacerbate invasive species impacts, TIE provides a promising approach to generate actionable ecological research while improving outcomes of invasive species management and policy decisions.

Keywords Conservation - Invasive species · Knowledge coproduction - Natural resource management · Translational ecology

\section{Introduction}

The disconnect between research, management, and policy-making (Pfeffer and Sutton 1999) leads to inefficiencies and missed opportunities to address pressing environmental problems (Matzek et al. 2015; Barney et al. 2019; Shackleton et al. 2019). Translational science, which integrates basic research and practice with the aim of improving outcomes, has been conducted for decades in the medical and human health fields (Littman et al. 2007), but has only recently been promoted in the fields of ecology and conservation (Schlesinger 2010). As environmental threats continue to grow (Barnosky et al. 2011; IPBES 2019), researchers and practitioners are increasingly embracing new paradigms that more deliberately engage a broader group of stakeholders (Lowe et al. 2009; Fisher et al. 2020). Translational ecology (TE) is an approach in which ecologists, stakeholders, and decision makers work together to develop research that addresses the sociological, ecological, and political contexts of an environmental problem (Enquist et al. 2017). TE emphasizes the need for long-term and deep engagement among these actors (Enquist et al. 2017), and relies on boundary spanners: organizations, groups, or individuals that act as a bridge between scientists and managers, generate products that enable communication between the two, and have accountability to both (Guston 2001; Safford et al. 2017). To strengthen the relationships and levels of trust between ecological researchers and practitioners and improve social and ecological outcomes, the framework of TE incorporates insights from approaches developed by social scientists such as knowledge co-production (Meadow et al. 2015) and participatory action research (Reason and Bradbury 2001).

As an interdisciplinary science that addresses invasive species impacts from global to local scales (Bellard et al. 2016; IPBES 2019; Hanley and Roberts 2019), invasion ecology is ripe for a translational approach that fosters sustained collaboration among researchers, stakeholders, and decision makers in order to identify, develop, and implement effective interventions. Invasive species introduction, spread, and impacts fall at the nexus of geopolitics (e.g., international trade), federal and state policy (e.g., National Invasive Species Act, state-level regulations on the planting/sale of individual species), and local governance (e.g., public resistance to management techniques such as herbicide application, lack of awareness of local invaders). This complex socio-political landscape creates unique constraints for on-the-ground management, which need to be considered when developing evidence-based invasive species management and policy recommendations. The scale of invasive species impacts requires widespread coordination (e.g., some biocontrol projects require intercontinental cooperation and information exchange), and multi-year to multi-decade commitments to develop effective, ecologicallygrounded management and policy solutions supported by stakeholder groups and the public.

Much attention and funding is dedicated to addressing invasive species, with global costs for control and management estimated at more than \$1.4 trillion annually (Lodge et al. 2016). However, despite the substantial financial and academic resources allocated to addressing invasive species, managers continue to report that they are losing ground to invasives (Beaury et al. 2020), in part due to a persistent mismatch between research focus and stakeholder needs (Matzek et al. 2015). This kind of mismatch, known across fields as the knowing-doing gap (Pfeffer and Sutton 1999; Foxcroft et al. 2020), stems from academics receiving little guidance to ensure their research is relevant and implementable (Hallett et al. 2017) as well as having limited access to funds for stakeholder-driven science (Hulme 2009), and managers having little incentive and/or limited support for implementing new information generated by research. 
Now more than ever, invasion ecology requires greater integration among research and practice (Funk et al. 2020). The rate of non-native species introductions shows no signs of slowing (Hulme 2009; Seebens et al. 2017), and other global changes, including increasing fire and other disturbances (Diez et al. 2012; Moloney et al. 2019; Fusco et al. 2019), climate change (Dukes and Mooney 1999; Hellmann et al. 2008; Bellard et al. 2013), and global trade (Hulme 2009; Lovett et al. 2016; Lockwood et al. 2019) challenge current approaches to invasive species management. These emerging challenges provide a clear opportunity to bring together researchers, stakeholders, and decision makers through a translational approach. Recent studies by Beaury et al. (2020) and Barney et al. (2019) indicate that managers and researchers are interested in advancing such collaborative approaches. We assert that a lack of a formal process for implementing such collaborations on invasive species issues has constrained broad implementation.

Here we propose a translational invasion ecology (TIE) approach, an extension of the translational ecology framework to address the knowing-doing gap between invasion ecology and management and policy. Expanding on the concept of translational ecology, we define TIE as an approach that embodies an intentional and inclusive process in which researchers, stakeholders, and decision makers collaborate to develop and implement ecological research via joint consideration of the ecological, sociological, economic, and/or political contexts in order to improve invasive species management. While the process of connecting research and practice is not novel (e.g., applied ecology/conservation, Cook et al. 2013; extension programs at land-grant universities, Reid et al. 2012), TIE builds on existing practices of stakeholder-driven research to form a unified framework, whereby each group contributes their perspective, expertise, and effort throughout the research process to generate new information and solutions. This process ideally results in improved decisionmaking, adaptive invasive species management, new research directions, and other shared benefits among a broad group of stakeholders.

TIE can be implemented within current institutional frameworks (Hallett et al. 2017); examples already exist (see case studies below). There is growing support for sustained, consistent relationships among researchers, stakeholders, and decision makers to implement TIE (Safford et al. 2017; Barney et al. 2019). Many invasives researchers and practitioners have already established the trusted relationships required for the process of successful translational science (Safford et al. 2017), but these collaborations could be supported and fostered more explicitly by institutions and funding agencies through a welldefined process within a TIE framework. Here we describe this framework, show examples of how it is already being successfully implemented, and discuss specific areas of invasion ecology that could especially benefit from TIE. Through three TIE case studies, we demonstrate how TIE can improve invasive species research, management, and policy outcomes.

\section{Translational invasion ecology}

The principles of TE are collaboration, engagement, commitment, communication, process, and decisionframing (Enquist et al. 2017). We apply these principles to TIE through five actionable steps (Fig. 1), which are relevant to other applications of TE as well. This process relies on robust discussion among ecologists, stakeholders, and decision makers who are invested in reducing invasive species introductions, spread, and/or impacts. We delineate the steps illustrated in Fig. 1 and illuminate them using three case studies (Boxes 1-3).

1. Define the problem/Identify relevant stakeholders

The steps of the TIE approach are non-linear, often revisited, and the starting point will depend on the context of the problem. Successfully progressing through the TIE process requires engaging researchers and stakeholders with a shared commitment to the problem at hand and a willingness to listen, learn, and collaborate to achieve a collective goal. Just like any successful relationship, the foundational Step 1 requires building trust, sincerely engaging in the process, and communicating frequently (Enquist et al. 2017). Relevant stakeholders, and the specific processes for identifying them, will also be contextdependent, driven by organizational capacity and desired project outcomes (Reed et al. 2009; de Vente et al. 2016). The process of defining the problem (Step 1) could begin with a knowledge gap that becomes a shared issue through TIE. For example, through a 


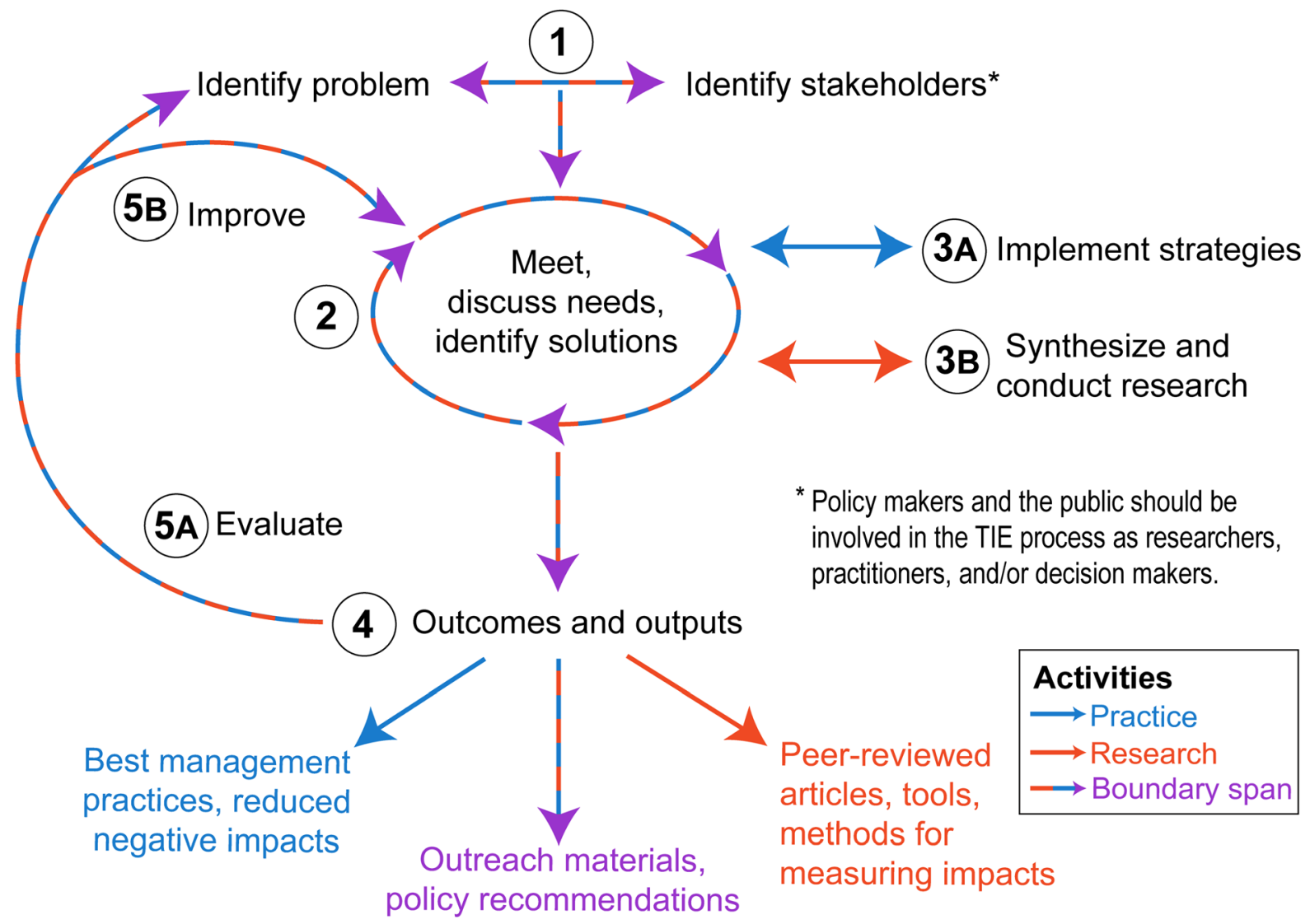

Fig. 1 The process of Translational Ecology (TE) in which research and practice work together through boundary spanning. Purple lines indicate opportunities for boundary spanning, in which practitioners (in blue) and researchers (in red) come together. Though steps are laid out in a semi-linear way, this

translational process catalyzed by the Maine Forest Service, researchers developed a project to better understand the biology of the wasp Cerceris fumipennis in order to assess its potential use as a biosurveillance agent for emerald ash borer (Agrilus planipennis; Lund 2015), a major concern for state foresters.

Step 1 could also begin with engagement of different stakeholders to identify overlap in shared goals and problems (e.g., Barney et al. 2019). Here, a boundary-spanning individual or organization may bring stakeholders together to have initial conversations and develop ideas for next steps (Box 1). There is no perfect method for identifying stakeholders, but including individuals with diverse backgrounds and process is iterative and TE can start at various points. This process is particularly needed for addressing the challenges of invasive species, as illustrated with the case studies presented below

knowledge has been shown to lead to more creative problem solving (Phillips 2014). Additionally, including student researchers and early career managers in the process often adds enthusiasm and a strong willingness to ask questions, which can be just as important as expertise to the process of TIE. Invasive species research and practice have a significant head start in engaging across boundaries. For example, there are numerous pre-existing partnership-based invasive species management programs representing specific geographies/jurisdictions (e.g., Cooperative Weed Management Areas, Invasive Species Councils). Some funding agencies require explicit partnerships between researchers and practitioners (e.g., the Australian Research Council) and have already or 


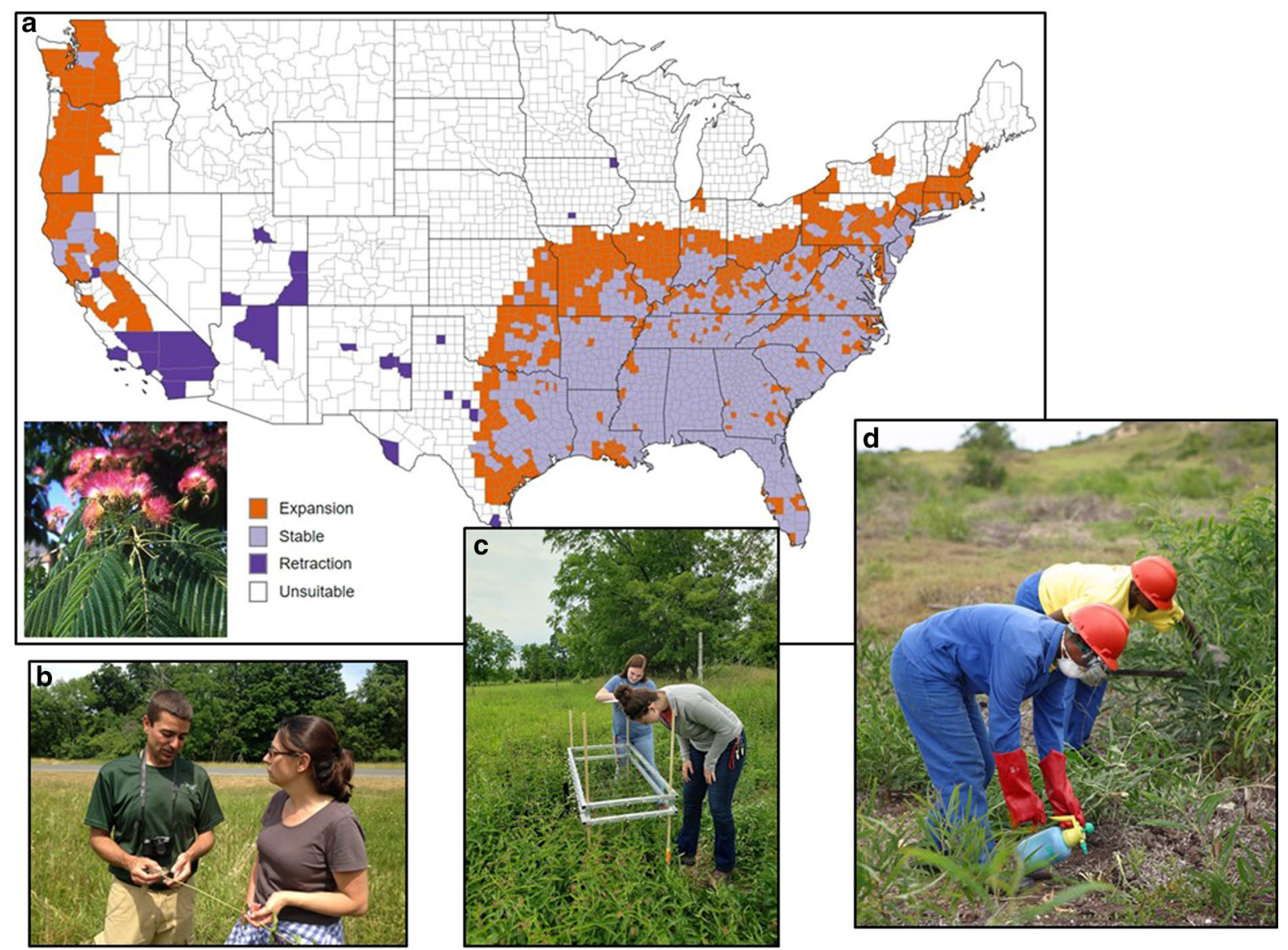

Fig. 2 Examples of Translational Invasion Ecology (TIE). a and b Conversations between researchers and managers (photograph by Carrie Brown-Lima, Cornell University, used with permission), supported by a boundary-spanning organization, yielded online maps of species potential range shifts with climate change (e.g., mimosa (Albiza julibrissin, shown), a species with biodiversity impacts and suspected fire resilience; photograph by Simon Garbutt, Public Domain). c Students set up monitoring plots to measure the effectiveness of a biological control agent (photograph by Jaclyn Schnurr, Wells College, used with permission). d Community members work to control invasive species as part of the Working for Water programme in South Africa (Photograph by Working for Water Programme, South Africa, used with permission). could take on the role of a boundary-spanning TIE organization.

\section{Collaborative discussion through boundary spanning}

Regardless of how TIE is initiated, the process hinges on collaborative discussions, in which researchers, stakeholders, and decision makers work together to determine needs and desired outcomes. This is where trust and commitment are built, resulting in clearly defined research, management, and policy needs to address the problem outlined in Step 1. Including participants from both research and practice is by definition a boundary-spanning activity (Guston 2001). Boundary spanning can happen through meetings, workshops, webinars, and with the help of organizations or individuals dedicated to facilitating discussion and collaboration. For example, the Central Coast Rangeland Coalition in California includes public land managers, private rangeland owners, University of California extension agents, and researchers, and this collective frequently provides a 
space for researchers and managers to exchange information and jointly vet potential projects (CCRC 2020). Boundary spanners can also be individuals (Safford et al. 2017), for example, when a researcher is embedded within a management organization (Cook et al. 2013; Roux et al. 2019) or when a research organization funds and rewards engagement with practitioners (e.g., University extension; Cook et al. 2013).

Boundary-spanning organizations could be especially useful for cases in which stakeholders have conflicting priorities and/or values. Facilitation by a third-party boundary-spanning organization can be critical to securing the legitimacy and trust needed to lower perceived barriers between stakeholders, and in turn, increase the likelihood of successful collaboration (Cash et al. 2006; Safford et al. 2017). For example, involvement of a third-party boundaryspanning organization might have reconciled the differing perspectives on fish stocking for recreational angling (including non-natives such as brown trout) and prevented the series of legal battles between anglers, environmental non-profits, and state agencies in California (Pister 2001; Lentz and Clifford 2014; Zieralski 2015). Rather than diving immediately into solving a problem, TIE provides a framework to identify existing knowledge gaps, collate information from stakeholders, correct false assumptions, and define next steps with measurable outcomes. By engaging in these conversations before taking action in Step 3, TIE ensures that near and long-term priorities for research, management, and policy are advanced systematically and incorporate a range of perspectives to effectively address the problem of invasive species.

\section{Research and practice}

Outcomes of collaborative discussion feed into research and practice, in which stakeholders' expertise comes into play. Steps 3A and 3B are not intended to happen in silos, but instead should be part of collaborative discussions among stakeholder groups with regular updates and opportunities for feedback. Over the last decade, invasive species managers have consistently reported that research fails to address management needs (Bayliss et al. 2012; Matzek et al. 2014, 2015), and managers often lack the resources (e.g., funding, personnel) to incorporate the steady stream of new information produced by research
(Matzek et al. 2014; Kuebbing and Simberloff 2015; Beaury et al. 2020). Folding perspectives from research and practice into the TIE process can avoid these barriers by promoting ecological research that addresses specific management needs, ensuring that research findings are accessible and can be implemented by managers and policymakers. For example, Box 1 illustrates a successful outcome of TIE's Step 3; by selecting management-relevant study sites, the research team facilitated rapid on-the-ground implementation of biocontrol releases. In Box 2, the boundary-spanning Regional Invasive Species and Climate Change (RISCC) Management Network facilitated Step 3 of TIE through a series of workshops aimed at ensuring that the research process and implementation were tightly linked.

\section{Outcomes/Outputs}

The goal of TIE is to increase our understanding of the ecology of invasions and our ability to manage invasive species introductions and impacts. There are additional benefits specific to researchers and stakeholders. For researchers, TIE can result in relevant, high impact, peer-reviewed publications and access to managers' context- and system-specific knowledge and data as well as experimental opportunities (Hallett et al. 2017). For practitioners, TIE can provide more robust scientific support for management decisions, develop best management practices, and support methods for measuring project success. These individual benefits can lead to shared benefits such as opportunities for researchers and practitioners to engage in stronger, more unified outreach with the public and policymakers, or to engage researchers from other disciplines (e.g., economists or environmental social scientists). In New York, researchers, resource managers, and boundary spanners came together to synthesize information about invasive forest insect and pathogen introduction pathways and impacts, which resulted in a high impact research publication (Lovett et al. 2016), policy recommendations, and advocacy for stronger federal regulations of global shipping practices (Lovett et al. 2019).

Other shared benefits of TIE include products such as tools to inform research and management (e.g., Jarnevich et al. 2019; Box 2), access to different types of funding sources (e.g., grants that support applied research or research implementation), and resourcesharing (e.g., supplies and personnel exchanges). For 
Table 1 Opportunities for future implementation of TIE

Aligning the focal species of researchers and managers

Understanding invasive species impacts and ecological vulnerability

Developing management strategies that are effective in the face of climate change

Employing emerging technologies for surveillance and management of invasive species

Defining and measuring outcomes of invasive species management strategies

Coordinating data collection and reporting of invasive species management programs

Informing public perception and policy to reduce invasion risk with a unified message from managers and scientists

instance, outcomes from the Great Lakes Phragmites Collaborative reflect diverse stakeholder priorities centered around a broad shared interest and a welldefined process (Braun et al. 2016). This group engages public and private land managers, researchers, and outreach and administrative professionals with the shared interest of controlling the invasive common reed (Phragmites australis) in the Great Lakes region. Their outcomes include best management practices, scientific studies, webinars, public outreach materials, tools for monitoring the invasion, and access to funding (Braun et al. 2016). As another example, the Field Manual for Managing Eastern White Pine Health in New England, which includes information about invasive pathogens, was developed as a result of a collaboration between researchers and resource managers in Maine and New Hampshire state agencies, the U.S. Forest Service, and the University of Maine (Livingston et al. 2019).

\section{Evaluate and improve}

Once outcomes are achieved, a critical final step in the TIE framework is to evaluate the process (Step 5A). Reflecting on successes and failures can improve current practices (Step 5B), highlight emerging knowledge gaps and indicate when stakeholders should iterate the TIE process (Step 1). Systematic ways of evaluating project results have already been developed; Wall et al. (2016) delineate categories of evaluation including process, outputs, outcomes, and impacts that can help highlight areas for improvement. For example, an issue in past attempts at translational ecology has been a failure to maintain a long-term commitment to open and consistent communication among stakeholders. Shackleton et al. (2019) found that researchers conducted surveys to inform research, but did not follow up with participants regarding their findings. This lack of two-way dialogue contributes to what is known as 'loading-dock' science (Enquist et al. 2017): researchers publish results with the hope that research will be implemented, but do not work with stakeholders to ensure that research outcomes are applied to real-world scenarios, nor do they ask for/ incorporate feedback about the distributed materials. TIE emphasizes open dialogue throughout the process to ensure outcomes are iteratively improved and relationships within the TIE framework are strengthened over time. Steps $5 \mathrm{~A}$ and $5 \mathrm{~B}$ are integral to building trust and encouraging dialogue among stakeholders (Enquist et al. 2017). As described in Box 2, once an online tool for identifying range shifting invasive species was developed, researchers, managers, and policymakers continued discussions through webinars and workshops to identify ways to improve and extend the tool's utility for informing policy and management decisions.

\section{Opportunities for TIE}

The examples in Boxes 1-3 demonstrate areas where TIE has been used to improve ecological research, management, and policy outcomes, but many other intersections between invasive species research and management could benefit from TIE (Funk et al. 2020; Table 1). Below we describe four of these high value target areas in further detail: 1) addressing the mismatch between research questions and management priorities, 2) facilitating uptake of new technologies and tools for invasive species prevention, surveillance and management, 3) defining appropriate metrics for measuring outcomes of invasive species 
Box 1 Transitioning a biological control agent from research to field testing and implementation (Fig. 2a and b)

\begin{abstract}
Identifying and testing biological control agents is a long-term research endeavor that takes place across distant geographies, in quarantine facilities and in field trials. Once the agent is approved for release, the research process continues, and field trials require coordination among the research community and the management agencies that release them. Recently, a network of invasive species managers in New York identified the development of biocontrol for swallow wort (Cynanchum spp.) as a top research need [Fig. 1(1)]. In response, the New York Invasive Species Research Institute (NYISRI), a boundary-spanning organization, identified the relevant stakeholders [Fig. 1(1)] and brought together researchers from four universities and the U.S. Department of Agriculture (USDA), managers from multiple state agencies, and stakeholders on the ground to discuss the problem [Fig. 1(2)]. They identified experimental study sites and potential funding opportunities. In collaboration with NYISRI and managers from across the state, researchers secured a $\$ 750,000$ grant to develop mass rearing techniques for the biocontrol agent, a monitoring protocol for researchers and managers, and experimental release plots across the state [Fig. 1(3b)]. NYISRI is currently working with managers to test the monitoring protocol [Fig. 1(3a)], and to create a way for this information to be recorded in the state's invasive species database [Fig. 1(4)]. This will allow for long-term compilation and sharing of data collected over a large area, facilitating the evaluation of the biocontrol agent's establishment rates and effectiveness across different habitats and helping to identify environmental variables associated with its success [Fig. 1(5)]. Because biocontrol agents take up to a decade to reduce a target invasive population, widespread and long-term monitoring is critical to evaluating outcomes. In this case, the Translational Invasion Ecology (TIE) process allowed researchers and managers to determine what monitoring data can and should be collected and provided resources to advance this work in an integrated way. NYISRI continues to serve as a boundary-spanning organization, facilitating communication on the project and coordinating efforts to secure additional funding for implementation [Fig. 1(5a,5b)]
\end{abstract}

Box 2 The Regional Invasive Species and Climate Change (RISCC) Management Network: Empowering proactive management of range-shifting invasive species (Fig. 2c)

The combined effects of invasive species and climate change pose novel risks for management, necessitating proactive planning for future changes in management practices, ecological vulnerability, and the identity of target invasive species. During several workshops between Northeast U.S. invasive species managers and scientists in 2016 and 2017 [Fig. 1(2)], it became clear that identifying the next invasive species likely to arrive due to climate change was a management priority [Fig. 1(1)]. Based on this need, a group of scientists and boundary spanners formed the Regional Invasive Species and Climate Change (RISCC) Management Network and successfully procured funds to develop a web-based tool to identify range shifting invasive plants [Fig. 1(4)] as well as new science to prioritize invasive plants arriving to the Northeast [Fig. 1(3b)]

The online tool relied on previous research that modeled the current and 2050 potential ranges of nearly 900 invasive plants in the U.S. (Allen and Bradley 2016). RISCC scientists partnered with the Early Detection and Distribution Mapping System (EDDMapS) to develop and host a customizable decision support tool that allows users to map the current and future distributions of range shifting invasive plants. The tool is now publicly available at https://www.eddmaps.org/rangeshiftlisting/. Using the new listing tool, RISCC scientists created a watch list for the New York + New England region by identifying range shifting species and then performing an impacts assessment on all species using the Environmental Impacts Classification of Alien Taxa (EICAT) protocol (Hawkins et al. 2015). From the original list of 100 range shifting invasive plant species, EICAT assessments identified 5 high-priority species likely to negatively impact native Northeast ecosystems, as well as agriculture, human health, or the economy (Rockwell-Postel et al. 2020)

RISCC researchers publicized new research and tools through listserv announcements, webinars, written outreach materials [Fig. 1(4)], and presentations at conferences. They solicited feedback about the tool in workshops and one-on-one conversations with stakeholders [Fig. 1(5a)]. They also hosted workshops with managers and policymakers to discuss the potential for managers to monitor species on watch lists and update regulatory lists to include watch list species [Fig. 1(4)]. The tools and impact assessments have been accessed over 280 times and improvements to the tool in response to user feedback are underway [Fig. 1(5b)]. While the process for this project did not follow a linear progression from Fig. 1 Step 1 to Step 5, it did (and continues to) include each step in the TIE process

interventions, and 4) addressing the lack of quantitative data on invasive species impacts.

TIE could help address the mismatch between project goals and foci of researchers versus managers (Matzek et al. 2015). For example, the invasive species that researchers are prioritizing (Pyšek and Richardson 2008; Hulme 2014) are frequently a small fraction of those that managers consider most important (Beaury et al. 2020). To begin to address the mismatch in studied versus managed species, initial 
Box 3 South Africa's Working for Water programme: A collaboration between researchers and managers to promote invasive species management and protect biodiversity and water resources (Fig. 2d)

One of the oldest and most well-documented examples of successful collaboration between scientists, managers, policy makers and communities to address widespread invasive species challenges is the Working for Water (WfW) programme in South Africa (Koenig 2009; van Wilgen and Wannenburgh 2016; Abrahams et al. 2019). WfW was established in 1995 to promote invasive species management efforts that would protect the fynbos shrublands of the Cape Floristic Region, a biodiverse area with high levels of endemism. In this area, invasive plants damage scarce water resources, biodiversity, and the economy. Scientists realized that national-level solutions required hydrologists, economists, entomologists, ecologists, and conservation biologists to engage across disciplines [Fig. 1(1)] to quantify and frame the problem [Fig. 1(2, 3b)] and to publish the scientific underpinnings upon which an invasive species management strategy could be built [Fig. 1(4)]. Researchers and managers worked collaboratively to propose management actions and then advocated for political and financial support to implement these actions [Fig. 1(2-3)]. Included in these actions were the development of 75 biological control agents for 45 collectively identified target invasive plant species. Additionally, the program helped reach political and social goals by employing and improving the well-being of community members who implemented the invasive species removal activities. Despite its great success as a model of knowledge co-production and manager-researcher partnerships, the project has also experienced the common shortcomings associated with invasive species management programs: resources were not allocated for strategic prioritization of invasive species management actions, and metrics to evaluate ecosystem-level effectiveness were not established. As a result, researchers and managers are uncertain if their efforts have achieved the initial goals of the program. Without taking Steps 5A and 5B, it was difficult to secure further funding for the program. Additionally, the challenges of working across academic, management and political spheres where priorities differ hindered the advancement of the original goals of the program. In the case of WfW, political pressure to increase employment shifted resources away from strategic prioritization, scientific monitoring, and development of improved management strategies that would have had greater benefits for invasive species management

meetings (coordinated by a boundary-spanning organization or individual) could focus on identifying emerging or understudied species and aligning potential research questions and data collection protocols with desired management outcomes. This process could produce new knowledge about the ecology and best management practices for invasive species which are still localized and have the greatest likelihood of eradication. Researchers could benefit by harnessing manager networks to expand and standardize data collection efforts focused on the early stages of invasion. In turn, managers could benefit from scientific analysis of priority targets for early detection and rapid response.

TIE also can facilitate the adoption and implementation of new tools for prevention, surveillance, and management. For example, drone remote sensing and environmental DNA (eDNA) are two promising technologies that can be used for early detection of invasive species (Trujillo-González et al. 2019; Reaser et al. 2020). Research on these technologies is expanding rapidly in the scientific literature, but key insights are not widely available, or applicable, to managers (Enquist et al. 2017). TIE can help identify the barriers to uptake of new technologies (e.g., funding, training), and ensure that they are of interest/ use in the first place. With trust and true collaboration, resource managers may be willing to take more risks and be more innovative. Moreover, using TIE to speed up the process of testing and applying these new tools will allow small-scale trials to expand to broad-scale implementation. For example, managers in the Northeast Aquatic Nuisance Species Panel collaborated with a researcher from the University of New Hampshire to apply new methods for using eDNA for the early detection of zebra mussels (Dreissena polymorpha) and Asian clams (Corbicula fluminea) in aquatic systems. Effective adoption of new tools will require boundary spanners to set up meetings for training and discussion. Managers could benefit from access to new methods that could increase effectiveness of prevention, surveillance, and/or management efforts while reducing costs. Researchers could benefit by advancing high impact research and patents focused on the most critical species and impacts, and by partnering with managers to evaluate the viability of those methods.

Measuring success in invasive species management is another important area that could benefit from TIE. As exemplified by the Working for Water programme in South Africa (Box 3), even high profile and wellfunded programs struggle to determine appropriate metrics of success, collect relevant data, and produce positive and lasting outcomes. TIE offers a unique 
opportunity to pair researchers and managers to formalize management programs into field experiments and create standardized metrics that assess conditions before and after intervention. The resulting information could be used to identify management approaches that optimize available resources and improve outcomes. Managers could benefit by gaining more persuasive proof of the benefits of treatments, researchers could benefit from a broader understanding of (as well as publications on) restoration outcomes across ecosystems, and ecosystems could benefit from more effective and strategic investments in reducing invasive species' impacts.

Lastly, invasion science and management suffer from a lack of quantification of the negative impacts of invasive species on ecosystems, economies, and human health. This weakens support from the public and policymakers for increased regulatory and control efforts to reduce introductions and negative impacts of non-native species. Thus, exotic organisms continue to be introduced to new areas through the ornamental plant industry (Beaury et al. in press; Mack and Erneberg 2002; Liebhold et al. 2012) and the exotic pet trade (Lockwood et al. 2019), despite regulations meant to curb the introduction and distribution of invasive species (e.g., U.S. state prohibited plant lists; Beaury et al. 2021) and border inspections of shipments (Springborn et al. 2016). TIE has the potential to bring together researchers, stakeholders, and decision makers to improve interventions, policy development, and enforcement that reduce the introduction and impacts of invasive species. Such collaborations can create outcomes that balance priorities of different stakeholders and increase public awareness about consumer choices that reduce invasive species spread and impacts.

\section{Conclusion}

As the Princess of Pure Reason says in The Phantom Tollbooth (Juster 1961), "What you can do is often simply a matter of what you will do." Broadly incorporating the TIE process across invasion ecology research, management, and policy will not be easy. Fortunately, it will not require a complete overhaul of current processes, but instead could be accomplished by improving or adapting existing processes (Beaury et al. 2020). The following activities are practical ways to begin advancing the TIE framework. (1) Support boundary spanning: Establish boundary-spanning positions within an organization or create/work with boundary-spanning organizations. If it is not possible to work with a designated boundary spanner, credit and incentivize time invested in boundary-spanning activities. Within the context of an academic institution, this might include building relationships with local management organizations, joining an existing collaboration, or encouraging graduate students to engage in TIE. Within a management organization, this might involve connecting to relevant graduate programs, where students are often in need of research projects. Beyond broader impacts statements, funding agencies can explicitly encourage, acknowledge, and reward efforts by researchers to engage in boundaryspanning activities or with boundary-spanning organizations. (2) Expand networks: In addition to attending academic conferences, researchers can prioritize regular attendance at management focused conferences and meetings. This will help them connect with resource managers and other stakeholders and decision makers. These connections will help to build relationships so as to more quickly identify emerging problems and enact potential solutions. (3) Share TIE experiences: Sharing concrete examples (successful and unsuccessful) of the TIE process can encourage others to adopt the TIE framework to meet their research and management goals. Sharing experiences in TIE can also help emphasize the importance of TIE to those with the power to create boundary-spanning organizations and positions. (4) Measure TIE outcomes: Indicators of successful knowledge coproduction (Meadow et al. 2015; Wall et al. 2016) can be adapted to evaluate processes effectively. For example, output metrics such as numbers of workshops and peer-reviewed articles are frequently measured, but impact metrics related to the actual use of information might better reflect research impact (Wall et al. 2016). Impact metrics could include measures of stakeholder engagement, commitment, adoption of research recommendations, and improved management outcomes.

Invasive species continue to exhibit enormous ecological, economic, and societal impacts, and these impacts are expected to intensify with global change. Enhanced cooperation among researchers and stakeholders is crucial to identify and implement strategies to reduce current and future invasive species impacts. The TIE framework can strengthen cooperation, 
enabling researchers and practitioners to successfully coproduce high priority knowledge, tools, and practices while reducing the knowing-doing gap and improving invasive species management outcomes.

Acknowledgements We thank Alyssa Rosemartin and an anonymous reviewer for their improvements to the manuscript. Funding was received from the U.S. Geological Survey Northeast Climate Adaptation Science Center USGS/NE CASC G19AC00091, including graduate fellowships awarded to E. Beaury and B. Laginhas, the National Science Foundation award BCS 1,740,267, and the National Science Foundation/ ICER-1852326 Belmont Forum Collaborative Research: Understanding and managing the impacts of invasive alien species on biodiversity and ecosystem services (InvasiBES).

Funding U.S. Geological Survey Northeast Climate Adaptation Science Center and the National Science Foundation.

\section{Declarations}

Conflicts of interest The authors declare that they have no conflict of interest.

Open Access This article is licensed under a Creative Commons Attribution 4.0 International License, which permits use, sharing, adaptation, distribution and reproduction in any medium or format, as long as you give appropriate credit to the original author(s) and the source, provide a link to the Creative Commons licence, and indicate if changes were made. The images or other third party material in this article are included in the article's Creative Commons licence, unless indicated otherwise in a credit line to the material. If material is not included in the article's Creative Commons licence and your intended use is not permitted by statutory regulation or exceeds the permitted use, you will need to obtain permission directly from the copyright holder. To view a copy of this licence, visit http://creativecommons.org/licenses/by/4.0/.

\section{References}

Abrahams B, Sitas N, Esler KJ (2019) Exploring integrative research in the context of invasive alien plant management. S Afr J Sci. https://doi.org/10.17159/sajs.2019/4263

Allen JM, Bradley BA (2016) Out of the weeds? Reduced plant invasion risk with climate change in the continental United States. Biol Conserv 203:306-312. https://doi.org/10. 1016/j.biocon.2016.09.015

Barney JN, Schenk T, Haak DC et al (2019) Building partnerships and bridging science and policy to address the biological invasions crisis. Invasive Plant Sci Manag 12:74-78. https://doi.org/10.1017/inp.2018.33

Barnosky AD, Matzke N, Tomiya S et al (2011) Has the Earth's sixth mass extinction already arrived? Nature 471:51

Bayliss HR, Wilcox A, Stewart GB, Randall NP (2012) Does research information meet the needs of stakeholders?
Exploring evidence selection in the global management of invasive species. Evid Policy A J Res Debate Pract 8:37-56

Beaury EM, Fusco EJ, Jackson MR et al (2020) Incorporating climate change into invasive species management: insights from managers. Biol Invasions 22:233-252. https://doi. org/10.1007/s10530-019-02087-6

Beaury EM, Fusco EJ, Allen JM, Bradley BA (2021) Plant regulatory lists in the U.S. are reactive and inconsistent. J Appl Ecol 00:1-10

Beaury EM, Patrick M, Bradley BA (In press) Invaders for sale: the ongoing spread of invasive plants by the plant trade industry. Front Ecol Environ

Bellard C, Cassey P, Blackburn TM (2016) Alien species as a driver of recent extinctions. Biol Lett 12:20150623

Bellard C, Thuiller W, Leroy B et al (2013) Will climate change promote future invasions? Glob Chang Biol 19:3740-3748. https://doi.org/10.1111/gcb.12344

Braun HA, Kowalski KP, Hollins K (2016) Applying the collective impact approach to address non-native species: a case study of the Great Lakes phragmites collaborative. Biol Invas 18:2729-2738. https://doi.org/10.1007/s10530016-1142-1

Cash DW, Borck JC, Patt AG (2006) Countering the loadingdock approach to linking science and decision making: comparative analysis of $\mathrm{El} \mathrm{Niño/Southern} \mathrm{oscillation}$ (ENSO) forecasting Systems. Sci Technol Hum Values 31:465-494. https://doi.org/10.1177/0162243906287547

CCRC (2020) Central Coast Rangeland Coalition. https://ucanr. edu/sites/CCRC/. Accessed 9 Feb 2021

Cook CN, Mascia MB, Schwartz MW et al (2013) Achieving conservation science that bridges the knowledge-action boundary. Conserv Biol 27:669-678. https://doi.org/10. 1111/cobi. 12050

de Vente J, Reed MS, Stringer LC et al (2016) How does the context and design of participatory decision making processes affect their outcomes? Evidence from sustainable land management in global drylands. Ecol Soc. https://doi. org/10.5751/ES-08053-210224

Diez JM, D'Antonio CM, Dukes JS et al (2012) Will extreme climatic events facilitate biological invasions? Front Ecol Environ 10:249-257. https://doi.org/10.1890/110137

Dukes JS, Mooney HA (1999) Does global change increase the success of biological invaders? Trends Ecol Evol 14:135-139. 5347(98)01554-7

Enquist CAF, Jackson ST, Garfin GM et al (2017) Foundations of translational ecology. Front Ecol Environ 15:541-550. https://doi.org/10.1002/fee.1733

Fisher JRB, Wood SA, Bradford MA, Kelsey TR (2020) Improving scientific impact: How to practice science that influences environmental policy and management. Conserv Sci Pract. https://doi.org/10.1111/csp2.210

Foxcroft LC, van Wilgen BW, Abrahams B et al (2020) Knowing-doing continuum or knowing-doing gap? information flow between researchers and managers of biological invasions in South Africa BT. In: Measey J, Richardson DM et al (eds) Biological Invasions in South Africa. Springer International Publishing, Cham, pp 831-853

Funk JL, Parker IM, Matzek V et al (2020) Keys to enhancing the value of invasion ecology research for management. 
Biol Invasions. https://doi.org/10.1007/s10530-02002267-9

Fusco EJ, Finn JT, Balch JK, et al (2019) Invasive grasses increase fire occurrence and frequency across US ecoregions. Proc Natl Acad Sci 116:23594 LP - 23599. https:// doi.org/10.1073/pnas.1908253116

Guston DH (2001) Boundary organizations in environmental policy and science: an introduction. Sci Technol Hum Values 26:399-408. https://doi.org/10.1177/ 016224390102600401

Hallett LM, Morelli TL, Gerber LR et al (2017) Navigating translational ecology: creating opportunities for scientist participation. Front Ecol Environ 15:578-586. https://doi. org/10.1002/fee. 1734

Hanley N, Roberts M (2019) The economic benefits of invasive species management. People Nat 1:124-137. https://doi. org/10.1002/pan3.31

Hawkins CL, Bacher S, Essl F et al (2015) Framework and guidelines for implementing the proposed IUCN Environmental Impact Classification for Alien Taxa (EICAT). Divers Distrib 21:1360-1363. https://doi.org/10.1111/ddi. 12379

Hellmann JJ, Byers JE, Bierwagen BG, Dukes JS (2008) Five potential consequences of climate change for invasive species. Conserv Biol 22:534-543. https://doi.org/10. 1111/j.1523-1739.2008.00951.x

Hulme PE (2009) Trade, transport and trouble: managing invasive species pathways in an era of globalization. J Appl Ecol 46:10-18. https://doi.org/10.1111/j.1365-2664.2008. 01600.x

Hulme PE (2014) EDITORIAL: Bridging the knowing-doing gap: know-who, know-what, know-why, know-how and know-when. J Appl Ecol 51:1131-1136. https://doi.org/10. $1111 / 1365-2664.12321$

IPBES (2019) Global assessment report on biodiversity and ecosystem services of the Intergovernmental Science-Policy Platform on Biodiversity and Ecosystem Services. IPBES secretariat, Bonn, Germany

Jarnevich CS, Cullinane Thomas C, Young NE et al (2019) Developing an expert elicited simulation model to evaluate invasive species and fire management alternatives. Ecosphere 10:e02730. https://doi.org/10.1002/ecs2.2730

Juster N (1961) Phantom tollbooth. Random House, New York

Koenig R (2009) Unleashing an Army to Repair Alien-Ravaged Ecosystems. Science (80- ) 325:562 LP - 563. https://doi. org/10.1126/science.325_562

Kuebbing SE, Simberloff D (2015) Missing the bandwagon: nonnative species impacts still concern managers. NeoBiota 25:73-86

Lentz DC, Clifford MA (2014) A synopsis of recent history of California's inland trout management programs: litigation and legislation. Calif Fish Game 100:727-739

Liebhold AM, Brockerhoff EG, Garrett LJ et al (2012) Live plant imports: the major pathway for forest insect and pathogen invasions of the US. Front Ecol Environ 10:135-143. https://doi.org/10.1890/110198

Littman BH, Di Mario L, Plebani M, Marincola FM (2007) What's next in translational medicine? Clin Sci 112:217-227. https://doi.org/10.1042/CS20060108

Livingston WH, Munck I, Lombard K et al (2019) Field manual for managing eastern white pine health in new England
Miscellane. University of Maine, Maine Agricultural and Forest Experiment Station, Orono, ME

Lockwood JL, Welbourne DJ, Romagosa CM et al (2019) When pets become pests: the role of the exotic pet trade in producing invasive vertebrate animals. Front Ecol Environ 17:323-330. https://doi.org/10.1002/fee.2059

Lodge DM, Simonin PW, Burgiel SW et al (2016) Risk analysis and bioeconomics of invasive species to inform policy and management. Annu Rev Environ Resour 41:453-488. https://doi.org/10.1146/annurev-environ-110615-085532

Lovett G, Weiss M, Lambert K (2019) Forest pests and pathogens in the United States: Community impacts and opportunities for Tree-SMART Trade. In: Cary Inst. Ecosyst. Stud. Sci. Policy Exch. www.caryinstitute.org/treesmart-trade

Lovett GM, Weiss M, Liebhold AM et al (2016) Nonnative forest insects and pathogens in the United States: impacts and policy options. Ecol Appl 26:1437-1455. https://doi. org/10.1890/15-1176

Lowe P, Whitman G, Phillipson J (2009) Ecology and the social sciences. J Appl Ecol 46:297-305. https://doi.org/10.1111/ j.1365-2664.2009.01621.x

Lund J (2015) Development of Cerceis fumipennis for Biosurveillance of the Emerald Ash Borer in the Northeast. https://digitalcommons.library.umaine.edu/etd/2409/

Mack RN, Erneberg M (2002) The united states naturalized flora: largely the product of deliberate introductions. Ann Missouri Bot Gard 89:176-189. https://doi.org/10.2307/ 3298562

Matzek V, Covino J, Funk JL, Saunders M (2014) Closing the knowing-doing gap in invasive plant management: accessibility and interdisciplinarity of scientific research. Conserv Lett 7:208-215. https://doi.org/10.1111/conl.12042

Matzek V, Pujalet M, Cresci S (2015) What managers want from invasive species research versus what they get. Conserv Lett 8:33-40. https://doi.org/10.1111/conl.12119

Meadow AM, Ferguson DB, Guido Z et al (2015) Moving toward the deliberate coproduction of climate science knowledge. Weather Clim Soc 7:179-191. https://doi.org/ 10.1175/WCAS-D-14-00050.1

Moloney KA, Mudrak EL, Fuentes-Ramirez A et al (2019) Increased fire risk in Mojave and Sonoran shrublands due to exotic species and extreme rainfall events. Ecosphere 10:e02592. https://doi.org/10.1002/ecs2.2592

Pfeffer J, Sutton RI (1999) Knowing "What" to Do Is not enough: turning knowledge into action. Calif Manage Rev 42:83-108

Phillips KW (2014) How diversity makes us smarter. Sci Am 311(4):43-47

Pister EP (2001) Wilderness fish stocking: history and perspective. Ecosystems 4:279-286. https://doi.org/10.1007/ s10021-001-0010-7

Pyšek P, Richardson DM (2008) Traits Associated with Invasiveness in Alien Plants: Where Do we Stand? In: Nentwig W (ed) Biological Invasions Ecological Studies (Analysis and Synthesis). Springer, Berlin

Reaser JK, Burgiel SW, Kirkey J et al (2020) The early detection of and rapid response (EDRR) to invasive species: a conceptual framework and federal capacities assessment. Biol Invasions 22:1-19. https://doi.org/10.1007/s10530-01902156-w 
Reed MS, Graves A, Dandy N et al (2009) Who's in and why? A typology of stakeholder analysis methods for natural resource management. J Environ Manage 90:1933-1949. https://doi.org/10.1016/j.jenvman.2009.01.001

Rockwell-Postel M, Laginhas BB, Bradley BA (2020) Supporting proactive management in the context of climate change: prioritizing range-shifting invasive plants based on impact. Biol Invasions. https://doi.org/10.1007/s10530020-02261-1

Roux DJ, Kingsford RT, Cook CN et al (2019) The case for embedding researchers in conservation agencies. Conserv Biol 33:1266

Safford HD, Sawyer SC, Kocher SD et al (2017) Linking knowledge to action: the role of boundary spanners in translating ecology. Front Ecol Environ 15:560-568. https://doi.org/10.1002/fee.1731

Schlesinger WH (2010) Translational Ecology. Science (80- ) 329:609 LP - 609. https://doi.org/10.1126/science. 1195624

Seebens H, Blackburn TM, Dyer EE et al (2017) No saturation in the accumulation of alien species worldwide. Nat Commun 8:14435. https://doi.org/10.1038/ncomms14435

Shackleton RT, Adriaens T, Brundu G et al (2019) Stakeholder engagement in the study and management of invasive alien species. J Environ Manage 229:88-101. https://doi.org/10. 1016/j.jenvman.2018.04.044
Springborn MR, Lindsay AR, Epanchin-Niell RS (2016) Harnessing enforcement leverage at the border to minimize biological risk from international live species trade. J Econ Behav Organ 132:98-112. https://doi.org/10.1016/j.jebo. 2016.03.011

Trujillo-González A, Edmunds RC, Becker JA, Hutson KS (2019) Parasite detection in the ornamental fish trade using environmental DNA. Sci Rep 9:5173. https://doi.org/10. 1038/s41598-019-41517-2

van Wilgen BW, Wannenburgh A (2016) Co-facilitating invasive species control, water conservation and poverty relief: achievements and challenges in South Africa's Working for Water programme. Curr Opin Environ Sustain 19:7-17. https://doi.org/10.1016/j.cosust.2015.08.012

Wall TU, Meadow AM, Horganic A (2016) Developing evaluation indicators to improve the process of coproducing usable climate science. Weather Clim Soc 9:95-107. https://doi.org/10.1175/WCAS-D-16-0008.1

Zieralski E (2015) California Fishermen Land Court Ruling. In: San Diego Trib. https://www.sandiegouniontribune.com/ sports/outdoors/sdut-outdoors-stocking-lawsuit-fisheries2015feb10-story.html

Publisher's Note Springer Nature remains neutral with regard to jurisdictional claims in published maps and institutional affiliations. 